\title{
Ultrastructural characterization of infection and colonization of Colletotrichum gloeosporioides in onion
}

\author{
Panday $\mathrm{SS}^{1}$, Alberto $\mathrm{RT}^{2 *}$ and Labe $\mathrm{MS}^{2}$ \\ ${ }^{1}$ Department of Agriculture and Fisheries, Autonomous Region in Muslim Mindanao-Integrated Agricultural Research, \\ Cotabato City, Philippines. \\ ${ }^{2}$ Department of Crop Protection, College of Agriculture, Central Luzon State University, Munoz, Nueva Ecija, \\ Philippines.
}

Panday SS, Alberto RT, Labe MS 2012 - Ultrastructural characterization of infection and colonization of Colletotrichum gloeosporioides in onion. Plant Pathology \& Quarantine 2(2), 168177, doi 10.5943/ppq/2/2/10

Anthracnose is the most destructive disease of onion in the Philippines. Infection by Colletotrichum gloeosporioides was studied by using light microscopy, transmission and scanning electron microscopy. At 6 hours after inoculation, a germ tube emerged from the conidium and a globular shaped appressorium formed from the end point of the germ tube. Between 24 to 48 hours after inoculation, the appressoria matured and an infection hypha emerged through a pore at the base of the appressorium. After 48 hours it penetrated the host cuticle directly and formed a primary hypha. Simultaneously, formation of papilla and penetration of the host through stomata also occurred although no evidence of an infection vesicle was observed. From 48 to 72 hours, primary hypha started to branch out to form secondary hyphae within the epidermal cells followed by a massive growth of both intra- and intercellular hyphae leading to the development of small whitish and water soaked lesions. At 72 to 96 hours after inoculation, intra- and intercellular hyphae radiated from cell to cell resulting in the formation of acervuli. At 96 hours after inoculation, typical onion anthracnose symptoms with salmon coloured mucilaginous spore matrix was observed on the infected leaf surface.

Key words - anthracnose - electron microscopy - pathogenicity

\section{Article Information}

Received: 9 October 2012

Accepted: 30 October 2012

Published online 25 November 2012

*Corresponding author: Ronaldo T. Alberto - bertyx1275@ hotmail.com

\section{Introduction}

Bulb onion (Allium cepa L.) is one of the most important food spices consumed all over the world in various forms. It occupies a prime position in the Filipino dietary habits and is one of the integral components of culinary preparations. Besides being used as condiment, its medicinal properties add to its value.
Onions in the Philippines are usually grown after rice when water is not sufficient for another rice cropping. Onion production fits very well in the rice farming system in selected regions of the Philippines. It is a good cash crop with high returns of investment (Lopez \& Anit 2000). Most (78\%) of total onion production is consumed as food or used as food 
ingredients, $10 \%$ is exported, $7 \%$ is used as seeds and 5\% accounts for other uses and waste.

In recent years, the area devoted to onion cultivation has expanded considerably. In 1999-2003, approximately 9,765 has. was planted to onion. Nueva Ecija (56.8\%) had the widest area and subsequently the highest producer with 53,312 metric tonnes. This was followed by Ilocos Norte (15\%) with 14,048 tonnes, Ilocos Sur (13.7\%) with 12,819 tonnes share, Pangasinan (12.4\%) with 11,599 tonnes, Nueva Vizcaya (1.2\%) with 1,117 tonnes. Other provinces nationwide accounted for $1 \%$ with 948 tonnes (DA-AMAS 2004). However, onion production in the Philippines has decreased since 1996. The highest production recorded so far was in 1998 at 86,978 tonnes and the lowest was in 1996 at 83,322 tonnes (Maghirang 2001). This scenario forced the Philippines to limit its export of onion.

Onion is subjected to a variety of diseases and disorders. Most of the diseases are caused by fungi and bacteria. Other disorders may be caused by adverse weather conditions, air pollutants, soil conditions, nutritional imbalances and pest control products. Diseases play a very important role in onion production. In 2000, an unusual outbreak of onion anthracnose occurred particularly in the province of Nueva Ecija and other onion growing provinces in Luzon. The disease was observed to have been uniformly distributed in the fields during the period of heavy rainfall and high humidity causing yield losses of as high as $80-100 \%$ (Alberto et al. 2001). The causal organism was identified as Colletotrichum gloeosporioides, one of the most common plant pathogenic fungi occurring in the tropics and sub-tropics and causing anthracnoses, necrosis, leaf spot, and fruit rots (Guarro et al. 1998).

Anthracnose is currently the most destructive disease of onion in the Philippines. The leaf disease phase can result in yield reduction by as much as $100 \%$ and rotting of bulb during and after storage for the bulb disease phase. Under Philippine conditions, effective management of onion anthracnose is still lacking. Sound management approaches require thorough knowledge of host-pathogen relations especially the stage when infection and colonization takes place. Although initial and post penetration characterization of $C$. gloeosporioides has been carried out in other crops (Anderson \& Walker 1961, Brown 1977, Chau \& Alvarez 1983, Dickman \& Alvarez 1983, Bergstrom \& Nicholson 1999) no studies have reported the biological processes and ultrastructural studies of $C$. gloeosporioides in onion.

This study was conducted to describe and document the pre- and post-penetration processes and ultrastructural characterization of infection and colonization of C. gloeosporioides in onion. Information on the duration of the pathogens development on onion leaves will provide empirical data to determine when management practices can be employed.

\section{Materials and Methods}

Collection and isolation of the pathogen - Onion plants infected with anthracnose were collected from onion fields in Nueva Ecija where anthracnose incidence were reported. Colletotrichum gloeosporioides was isolated from the heavily sporulating lesions of anthracnose-infected onion leaves. The pure culture of the pathogen was overlayed with mineral oil prior to storage in the refrigerator.

Preparation of inoculum and inoculation - Pure cultures of $C$. gloeosporioides were grown on acidified (2-3 drops of $20 \%$ lactic acid per plate) potato dextrose agar for 14 days in complete darkness to obtain maximum sporulation. Spore suspension of the pathogen was prepared by adding $50 \mathrm{ml}$ of sterile water per plate followed by scraping of the fungal growth with a sterile wire loop. The fungal suspension was filtered by sterilized cheesecloth. Spore density was adjusted to $2 \times 10^{6}$ spores $^{-\mathrm{ml}}$ using a haemocytometer. A drop of sticker was added per $50 \mathrm{ml}$ of fungal suspension prior to inoculation to assure adhesion of the spores on onion leaf surface. Inoculation was done by spraying the conidial suspension on 8-week-old onion seedlings. To ensure uniform and dense infection of all leaves, inoculation was repeated by gradually rotating the pots so that each side faced upwards once. After inoculation, the pots were kept stationary for about 3 min to allow the spores to settle. The plants were incubated in a darkened incubation chamber for at least 
72 hours at $28^{\circ} \mathrm{C}$ and later placed in an elevated platform inside the greenhouse.

Sampling - Leaf samples were collected at 4, 6, 12, 24, 36, 48, 72, 96, and 120 hours after inoculation (HAI) by cutting at least $201-2 \mathrm{~mm}^{2}$ tissue sections per sample from the inoculated leaves approximately midway between the leaf base and the leaf tip where most of the conidia were presumed to be located due to water droplets that accumulated on the leaves.

Preparation and microscopic observation of samples - The methods of Rushing \& Latham (1992) for the preparation of samples for scanning electron microscopy (SEM) and transmission electron microscopy (TEM) were adopted. For light microscopy (LM) the procedure of Clark (1992) was followed with some modifications based on the standard procedure in sample preparation of the Electron Microscopy Service Laboratory, National Institute of Molecular Biology and Biotechnology (BIOTECH), University of the Philippines, Los Banos, Laguna, Philippines.

Samples for SEM were immediately fixed for 18 hours at $4{ }^{\circ} \mathrm{C}$ in gluteraldehydeacrolein to stabilize and preserve the ultrastructure of the fungus. Then, the samples were rinsed for 15 minutes twice in $0.01 \mathrm{M}$ sodium cacodylate buffer ( $\mathrm{pH}$ 7.2) and once in distilled water. Samples were dehydrated in a graded ethanol series to partially remove water content of the samples since water deflects the electron beam which blurs the image (Bozzola \& Russel 1999). After the last change of ethanol, the samples were subjected to critical point drying in a critical point dryer (Hitachi HCP-2, Hitachi, Japan) with $70 \%$ ethanol as the intermediate solvent while carbon dioxide was the transitional fluid to avoid the damaging effects of surface tension. Samples were mounted on stubs and were coated with gold per palladium at $10 \mathrm{~mA}$ and 85 millitorr in a sputter coater (Jeol Ion Sputter JFC-1100) for 2 minutes to improve contrast. This was followed by examination under a Jeol JSM$6301 \mathrm{~F}$ scanning electron microscope.

For TEM, samples taken at 48, 72, 96, and $120 \mathrm{HAI}$ were treated with glutaraldehyde, buffer, and ethanol series in the same way described for the SEM. After the ethanol series, samples were treated with two changes of propylene oxide and transferred in disposable tissue culture dishes. These were infiltrated with $100 \%$ resin to provide a stable and hard matrix throughout the tissue for thin sectioning.

Resin-treated samples were placed in a vacuum oven at $70^{\circ} \mathrm{C}$ for 36 hours for embedding. Then the bulk embedded samples were removed from the culture dishes and placed on the stage of a light microscope to locate and orient fungal structures on the leaves for sectioning. Thin sections for TEM, approximately $800 \mathrm{~A}^{\circ}$ were cut using a diamond knife and these were collected on slot grids and dried on formvar-coated aluminum racks. Sections were post-stained with $5 \%$ uranyl acetate for 40 minutes and with lead citrate for 20 minutes before examination in a TEM (JEOL 1220) at $80 \mathrm{KV}$.

For light microscopy works, samples taken at $48,72,96$, and 120 HAI were treated with glutaraldehyde, buffer, ethanol series and propylene oxide infiltrated with resin. These were polymerized in the same way as TEM was done. The tissue sections were cut approximately $1 \mu \mathrm{m}$ with a Sorval Porter Microtome MT-2 and post-stained with $6 \%$ toulidine blue.

\section{Results and Discussion}

Spore germination and appresoria formation - The ungerminated conidium settled on the depressed portions of the onion leaves. Six hours after inoculation, the conidia germinated and produced a short germ tube that emerged from one side of the conidium (Fig. 1A). This result showed some resemblance with the light microscopy reports of Alberto et al. (2003). At an average of 16 hours, the germ tube formed a globose-shaped appresorium at the tip reaching its full growth between 36-48 hours (Fig. 1B). This observation was similar to the findings of Wharton et al. (2001) on C. sublineolum in sorghum (Sorghum bicolor) under SEM. The appresoria were dark brown, globose and were in immediate contact with the epidermal layer of the host. The same was reported in $C$. truncatum in lentin (Lens culinaris) by Chongo et al. (1998), in papaya fruit by Chau \& Alvarez (1983), in alfalfa by Miguel et al. (1998), in maize by Mims \& Vaillancourt (2002), and in onion by (Alberto et al. 2003). 


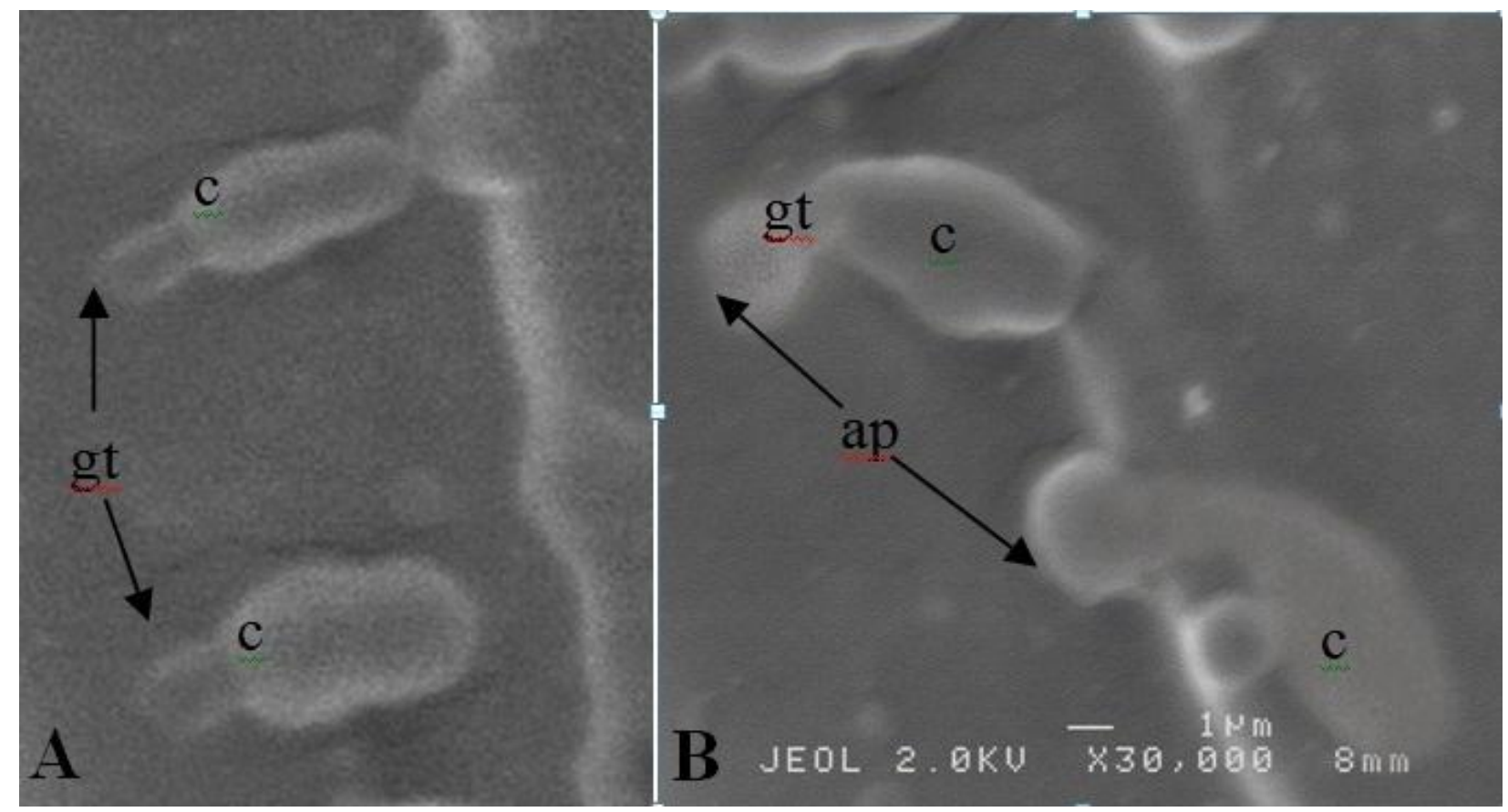

Fig. 1 - Scanning electron micrograph of (A) germ tube (gt) of C. gloeosporioides emerging from the conidia (c) at 6 HAI and (B) appresorium (ap) between 12 to 24 hours after inoculation
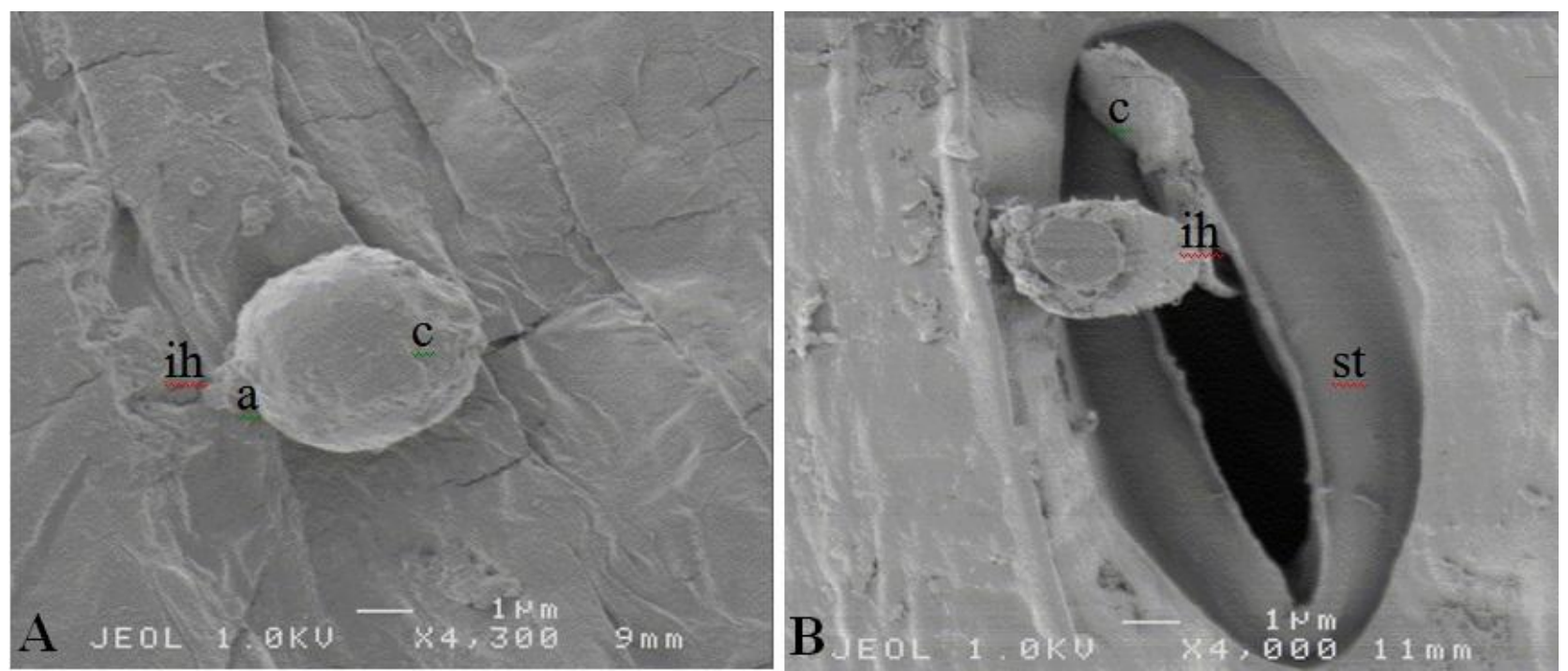

Fig. 2 - Scanning electron micrograph of (A) direct penetration of C. gloeosporioides on onion leaf at 48 HAI (note the infection hypha (ih) germinating from the appressorium (a) and (B) penetration through stomatal opening (note the infection hypha (ih) penetrating through the stomatal (st) opening

Host penetration and development of the infection process - Direct penetration through intact plant surfaces and through natural openings like the stomata were observed in this study. At $48 \mathrm{HAI}$, infection hypha germinated from the base of an appresorium and forcibly penetrated the host cell directly through mechanical pressure (Fig. 2A). These findings were consistent with the reports of Anderson \& Walker (1961) on watermelon and Alberto et al. (2003) on onion which show that $C$. gloeosporioides can exert enough mechanical force to penetrate its host. Direct penetration is the most common means of tissue penetration by necrothropic fungal pathogens (Bailey et al. 1992). Also, at 48 HAI, an infection hypha from another conidium emerged from the base of the 

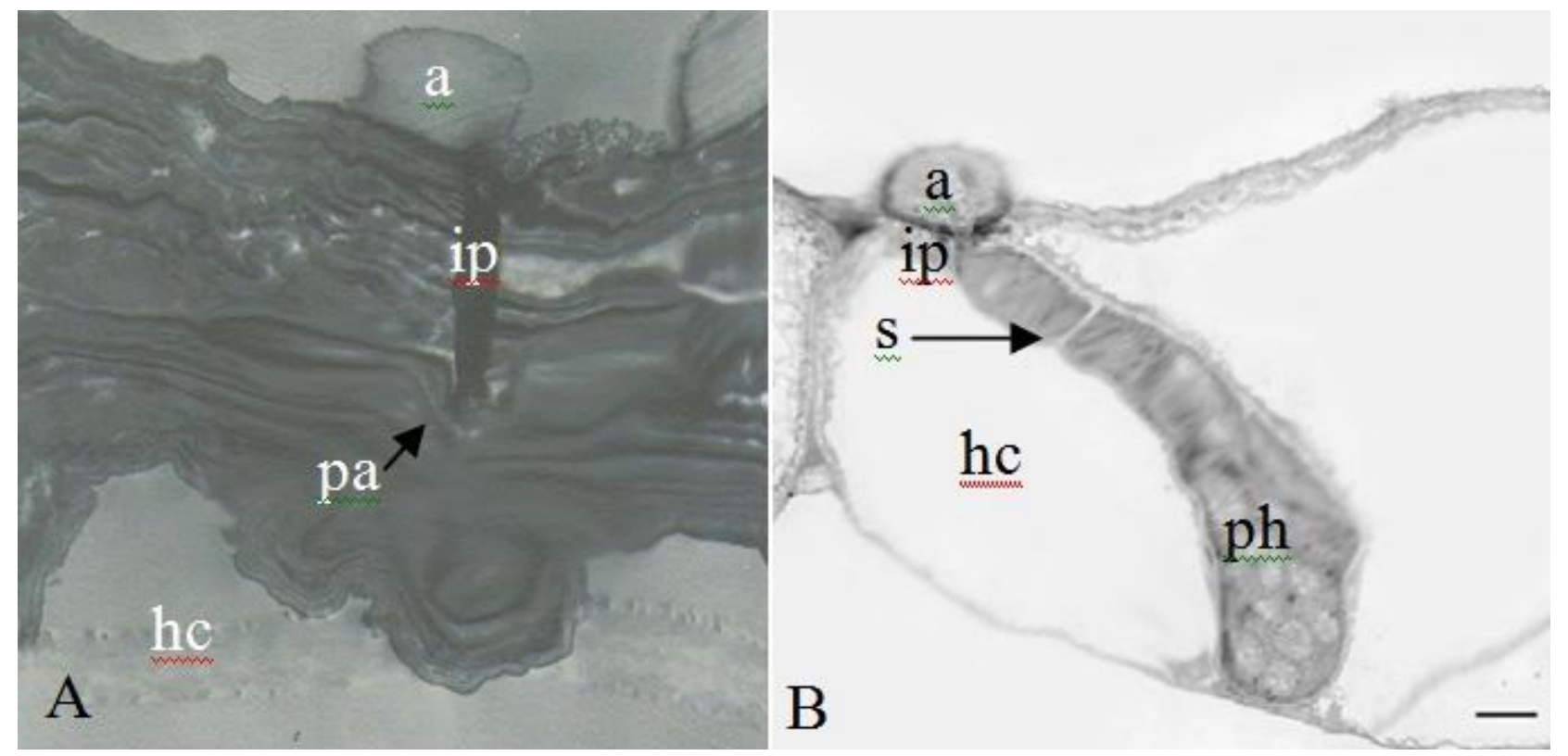

Fig. 3 - Transmission electron micrograph of (A) the penetration of onion epidermal cell by $C$. gloeosporioides at $48 \mathrm{HAI}$. An appressorium (a) has given rise to an infection peg (ip) encased by a papilla (pa) and (B) appressorium (a) penetrated the epidermal cell and formed primary hypha (ph) with a single septum (s) 48 to 72 HAI. hc-host cytoplasm
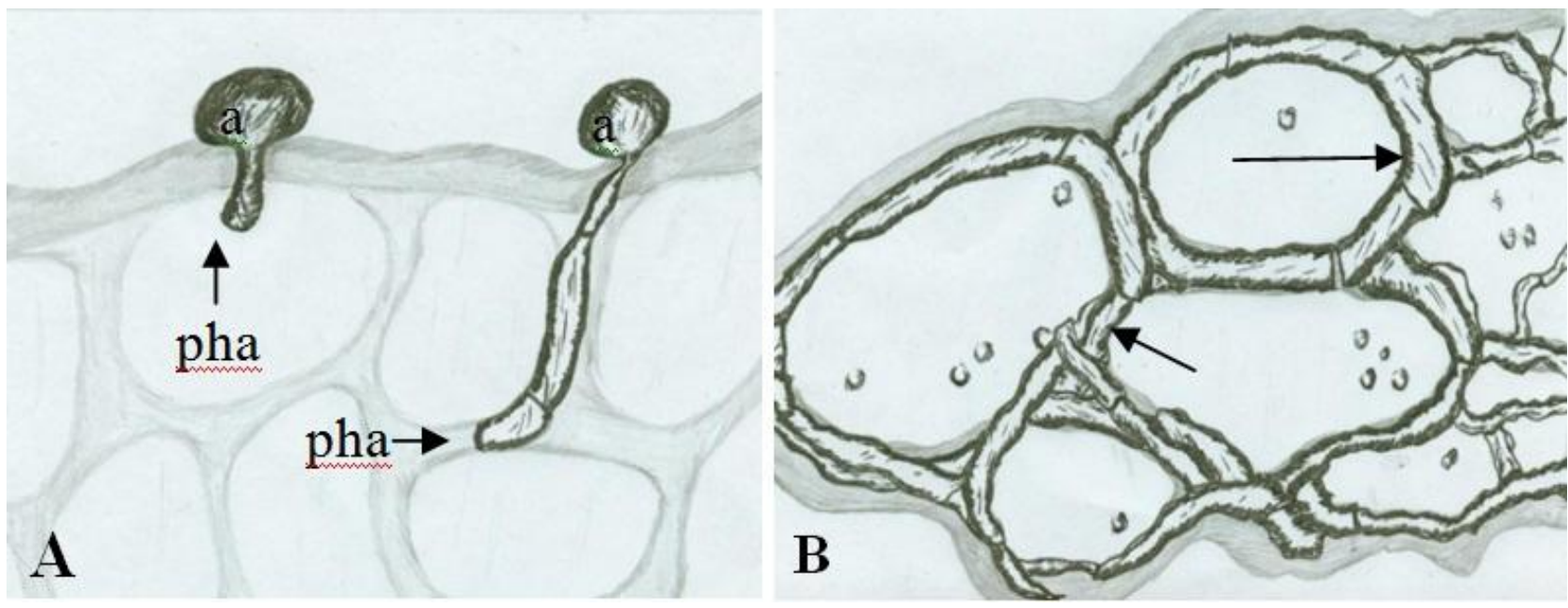

Fig. 4 - (A) Cross section of two infection sites of $C$. gloeosporioides stained with toulidine blue showing appressorium (a) with intracellular primary hypha (pha) and intercellular primary hypha penetrating the host cell at $72 \mathrm{HAI},(B)$ intercellular growth of hyphae (arrows, re-drawn from TEM photomicrographs)

appressorium and penetrated the host through the stomatal opening of the onion leaf (Fig. 2B). A similar observation was reported by Senechal et al. (1987) on C. gloeosporioides in rubber (Hevea brasiliensis).

To hasten the direct cuticle penetration, C. gloeosporioides also produces cutindegrading enzymes to dissolve or soften the host cuticle prior to penetration. This was reported on $C$. gloeosporioides, $C$. lagenarium, and $C$. capsici. These species can produce esterases and cutinase. An example of this is di-isoprophyl flourophosphate (DFP) that is capable of degrading cutin (Bailey et al. 1992).

In the TEM examination, formation of papilla by the host cell was also observed at 48 HAI (Figure 3A). The formation of papilla by the host plant was triggered by the presence of the invading pathogen. The papilla served as an induced resistant mechanism of the host 


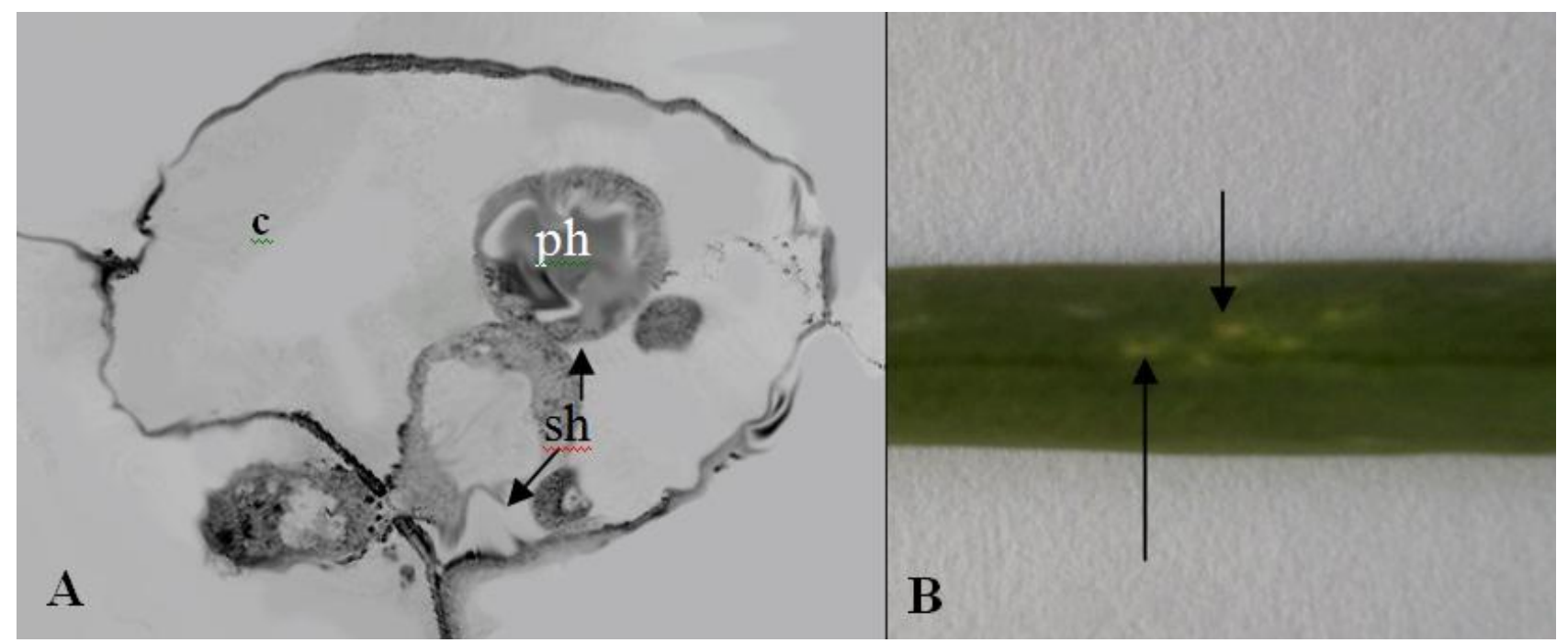

Fig. 5 - (A) Transmission electron micrograph of the primary hyphae (ph) of C. gloeosporioides branching out secondary hyphae (sh) within the cytoplasm (c) of the epidermal cell and radiating into adjacent cell at 72 HAI. (B) small water-soaked lesions on onion leaf (arrows)
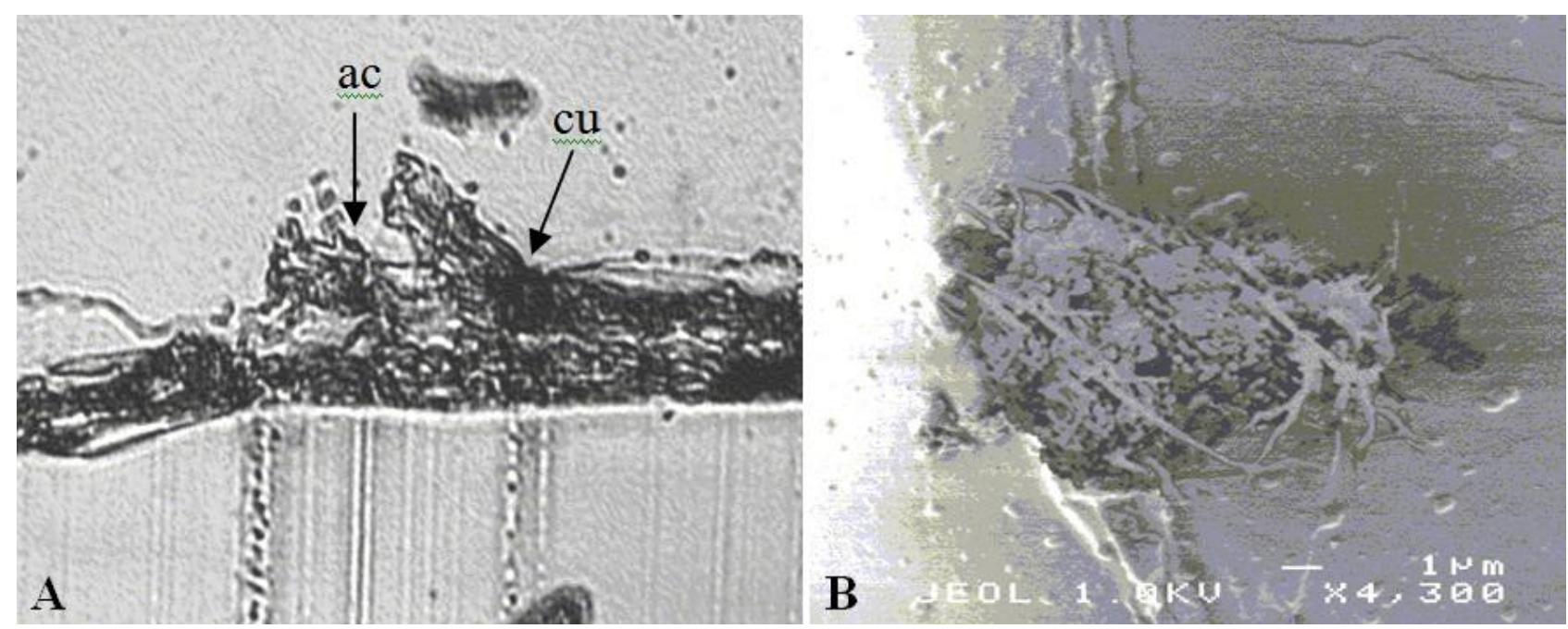

Fig. 6 - (A) Photomicrograph of the cross section of the initial formation of acervulus (ac) protruding through the cuticle (cu) and (B) scanning electron micrograph of an acervulus of $C$. gloeosporioides on the leaf surface of onion at 72-96 HAI

against the penetrating organism. This finding was similar to what was reported on tangerines. This showed that C. gloeosporioides is a typical intercellular pathogen that does not kill cells in advance stage of invasion after penetration (Brown 1977). Moreover, a penetration pore developed at the base of the appressorium and an infection peg emerged through a pore and penetrated the cuticle and epidermal cell wall. However, electron microscope examination revealed no evidence of the formation of infection vesicle on onion as what has been reported in corn by (Bergstrom \& Nicholson (1999).
By 48 to 72 HAI, formation of primary hypha was observed intracellularly. The hypha further elongated for several micron and became septate and larger (Fig. 3B). The hyphal wall appeared to have a close contact with the host plasma membrane with no interfacial matrix separating them. The absence of special interface matrix between the fungal hypha and host plasma membrane limits the duration of initial symptomless infection or biotrophic phase of infection (Wharton et al. 2001). During this phase, the pathogen invades host cells without killing them. By 72 HAI, the pathogen shifted to a necrotrophic phase of 


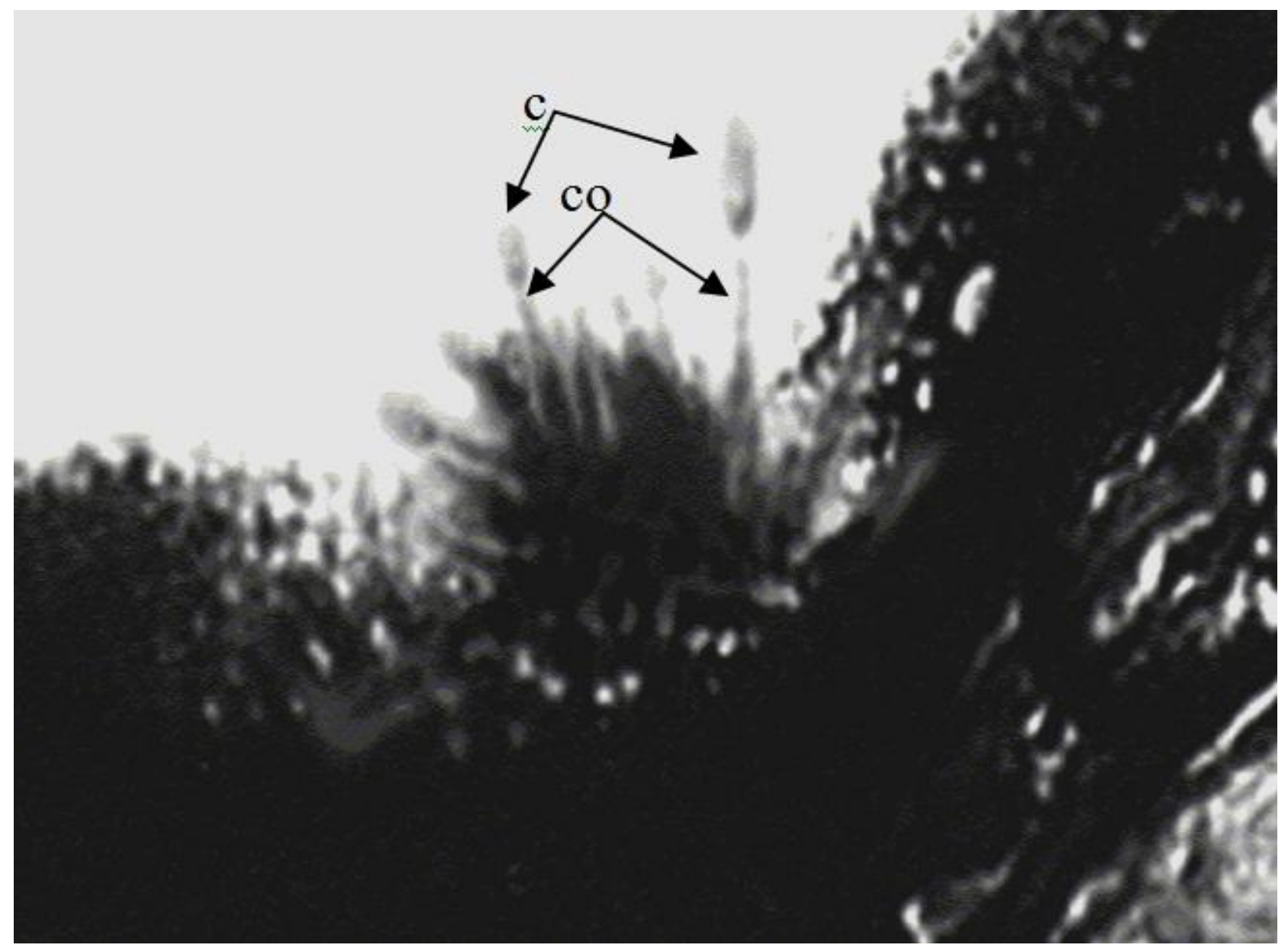

Fig. 7 - Photomicrograph of the cross section of acervulus of $C$. gloeosporioides protruding through the culticle with conidiophore (co) and conidia (c) at $72-96 \mathrm{HAI}$.

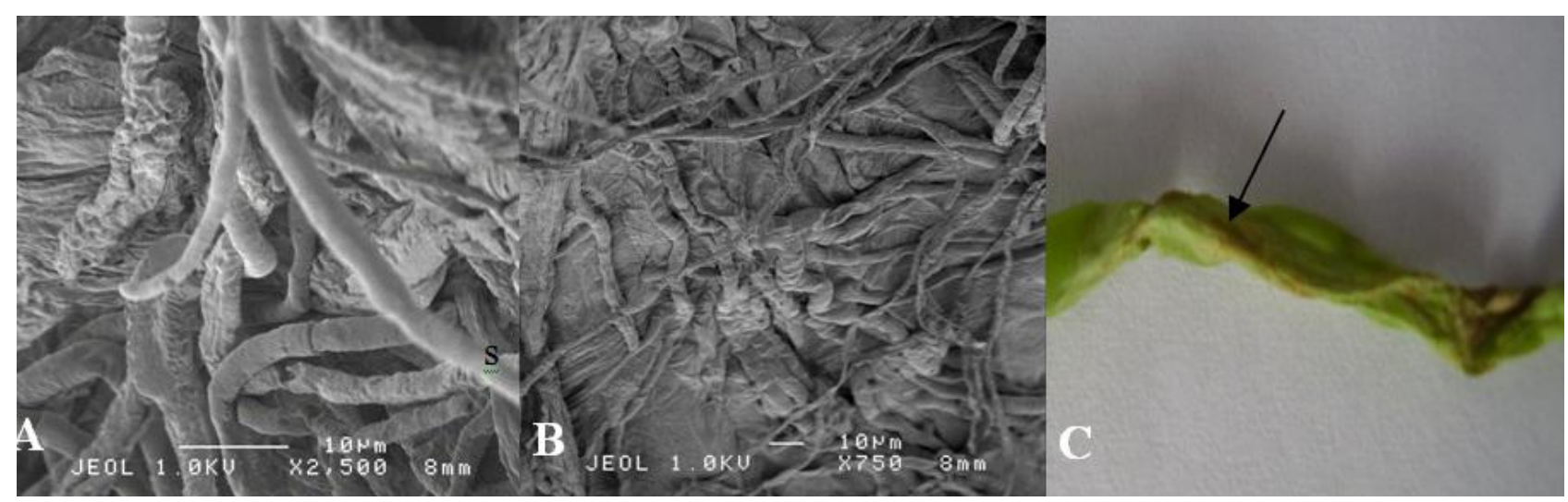

Fig. 8 - Scanning electron micrograph of the massive growth of mycelia of $C$. gloeosporioides at (A) $96 \mathrm{HAI}$ and at (B) $120 \mathrm{HAI}$, (C) salmon colored mucilaginous matrix on the leaf surface (arrow) at $96 \mathrm{HAI}$

infection. Both intracellular and intercellular growth of primary hyphae was observed (Fig. 4A).

Primary and secondary hyphae proliferated throughout the host tissues growing both intra-cellularly and intercellularly and causing massive damage and dissolution of the cell wall (Fig. 4B). This meant that the pathogen produced enzymes, which were responsible in degrading the host tissues. Polygalacturonases, pectin lyases and proteases are the cell wall degrading enzymes considered to have roles in establishing infection and tissue dissolution (Bailey et al. 
1992). Examination of samples under the TEM revealed that narrow secondary hyphae started to branch out from the primary hypha within host epidermal cell that is surrounded by the host cytoplasm. These radiated into the adjacent epidermal and mesophyll cells allowing the pathogen greater access for nutrients from the host cells (Fig. 5A). At this stage, the pathogen switched to a necrotrophic phase of infection.

As the primary hyphae and secondary hyphae advanced from cell to cell, the infected cells gradually lost their viability because the cytoplasm become disorganized leading to the appearance of a small water-soaked lesions on the onion leaf surface (Fig. 5B).

Through light and scanning electron microscopy, an acervulus was observed protruding through the host cuticle (Fig. 6A, B) at 72 to $96 \mathrm{HAI}$. A number of primary and secondary hyphae were observed forming into an acervulus that gave rise to conidiophores and mass of conidia (Fig. 7). Mycelia were observed growing on the leaf surface of the host plant starting at 96 HAI (Fig. 8A). At 120 HAI, extensive mycelial growth was observed (Fig. 8B). This lead to the development of typical anthracnose symptoms (Fig.8C). This symptom appeared as salmon coloured mucilaginous matrix developing further into black acervuli arranged in concentric rings. The same was observed in necrotic areas of infected leaves by Alberto et al. (2001).

Finally, infection on onion leaves by $C$. gloeosporioides as observed under light and electron microscopes became visible at 96 HAI. The summary of the processes and development of infection is shown in Table 1.

Table 1 Summary of development of infection of C. gloeosporioides on onion leaves

\begin{tabular}{lll}
\hline \multicolumn{1}{c}{ Stages } & Symptoms & HAI* \\
\hline Spore germination & - & 6 \\
Appressoria formation & - & $12-24$ \\
Host penetration & - & 48 \\
$\bullet \quad$ Direct & - & 48 \\
$\bullet \quad$ Natural opening & - & 48 \\
Papilla formation & Small water soaked lesions & 72 \\
Primary and secondary hyphae formation & Typical anthracnose symptom & 96 \\
Acervulus formation & Presence of salmon colored mucilaginous & 96 \\
Mycelial growth formation on leaf surface & matrix on infected leaf & \\
Extensive mycelial growth & Typical anthracnose symptom & 120 \\
formation on leaf surface & &
\end{tabular}

* hours after inoculation

\section{Summary and Conclusion}

The ultrastructure of infection of onion leaves by Colletotrichum gloeosporioides was studied through light and electron microscopy. A short single germ tube emerged from the conidium that settled on the depressions of onion leaves 6 HAI. Early formation of appressorium started at 12 HAI further developing into a matured appressorium between 24 and 48 HAI. Infection hypha emerged through a pore at the base of an appressorium and forcibly penetrated (direct) the host epidermal cell at 48 HAI. Other conidia used stomatal openings as entry points in penetrating the host plant. Papilla was formed at $48 \mathrm{HAI}$ which served as the resistant mechanism of the host plant against the invading pathogen. No formation of infection vesicles was observed.

The infection hypha became elongated and septated resulting in larger primary hypha. At this stage of infection, the pathogen invaded the host cells without killing them. Subsequently at $72 \mathrm{HAI}$, the pathogen shifted to its necrotrophic phase where a narrow secondary hyphae started to branch out from primary hypha within the host epidermal cell. This was followed by the massive growth of both intra- and intercellular hyphae. As the primary and secondary hyphae radiated from cell to cell, infected cells gradually lost their viability and a small whitish water-soaked lesion appeared on the surface of the leaves.

Initial formation of acervulus protruding through a cuticle occurred at 72-96 
HAI. Primary and secondary hyphae formed an acervulus giving rise to conidiophores and mass of conidia. Extensive growth of mycelial hyphae on the surface of the onion leaves and orange mucilaginous spore matrix were observed during this period. This further developed into black acervuli arranged in concentric rings on the infected portion of onion leaves. This development was a typical symptom of anthracnose at $120 \mathrm{HAI}$.

Under favorable field conditions, anthracnose in onion can easily develop into an epidemic proportion since it took only at least 96 hours for the $C$. gloeosporioides to complete its cycle in onion leaves. This is a classical example of a polycyclic disease whereby the pathogen can easily produce many disease cycles resulting in millions of inoculum in one growing season. Since no resistant commercial onion cultivars are available in the market at the moment, protection of the host plant at an early stage is necessary.

\section{Acknowledgement}

The authors wish to thank the Department of Agriculture - Bureau of Agricultural Research for funding the research.

\section{References}

Alberto RT, Duca SV, Santiago SE, Miller SA. 2001 - First report of anthracnose of onion (Allium cepa L.) caused by Colletotrichum gloeosporioides (Penzig) Penzig \& Sacc.) in the Philippines. Journal of Tropical Plant Pathology 37(1), 46-51.

Alberto RT, Tiedeman AV, Wolf G, Danzinger HL. 2003 - Light microscopy study on the pathological histology of Colletotrichum gloeosporioides (Penzig) Penzig and Sacc. in onion. Journal of Tropical Plant Pathology 38, 47-51.

Anderson JL, Walker JC. 1961 - Histology of watermelon anthracnose. Phytopathology $52,650-654$.

Bailey JA, O'Connel RJ, Pring RJ, Nash C. 1992 - Colletotrichum: Biology, Pathology and Control. C.A.B. International, Wallingford. p. 88-120.

Bergstrom GC, Nicholson RL. 1999 - The biology of corn anthracnose. Plant
Disease 63, 596-608.

Bozzola JJ, Russel LD. 1999 - Electron Microscopy, Principles and Techniques for Biology. $2^{\text {nd }}$ ed. Massachusettes, Jones and Barlett. p. 33-52.

Brown GD. 1977 - Ultrastructure of penetration of ethylene-degreened Robinson tangerines by Colletotrichum gloeosporioides. Phytopathology 67, 315-320.

Chau KF, Alvarez AM. 1983 - A histology study of anthracnose on Carica papaya. Phytopathology 73, 1113-1116.

Chongo G, Gossen BD, Bernier CC. 1998 Infection by Colletotrichum truncatum in resistant and susceptible lentil genotypes. Canadian Journal of Plant Pathology (1), 81-85.

Clark CA. 1992 - Histology evidence the Fusarium latertium is an exopathogen on sweetpotato with chlorotic leaf distortion. Phytopathology 82, 656-663.

DA-AMAS, 2004 - Onion factsheet. 2003. Retrieved August 11, 2006 from http://www.da.gov.ph/agribiz /commodityfactsheet_onion.html.

Dickman MB, Alvarez AM. 1983 - Latent infection of papaya caused by Colletotrichum gloeosporioides. Plant Disease 67, 748-750.

Guarro JT, Svidinski E, Zaror L, Forjaz MH, Gene J, Fischman O. 1998 Subcutaneous hyalohyphomycosis caused by Colletotrichum gloeosporioides. Journal of Clinical Microbiology 36(10), 3060-3065.

Lopez EL, Anit EA. 2000 - Allium production in the Philippines. Retrieved July 14, 2006 from http://www.actahort.org/ books/358/358_8.html

Maghirang RG. 2001 - Onion production. Veggies Today. Retrieved August 11, 2006 from http://www.bar.gov.ph/vegrde VeggiesTodayVol2-2.html.

Miguel D, Porto M, Grau R, de Zoeten GA, Gaard GA. 1998. Histology of Colletotrichum trifolii on alfalfa. Journal of Phytopathology 78, 345-349.

Mims CW, Vaillancourt LJ. 2002. Ultrastructural characterization of infection of maize leaves by Colletotrichum gramanicola, and by a $C$. gramanicola pathogenicity mutant. 
Plant Pathology \& Quarantine — Doi 10.5943/ppq/2/2/10

Phytopathology 92, 803-811.

Rushing AE, Latham AJ. 1992. Some ultrastructural observations of Cladosporium caryigenum growth in pecan leaves. Phytopathology 81, 1102-1108.

Senechal Y, Sanier C, Gohet E, Dauzac J. 1987. Different ways of penetration of
Colletotrichum gloeosporioides into the leaves of Hevea brasiliensis. Phytopathology 305, 537-542.

Wharton PS, Julian AM, O'Connel RJ. 2001. Ultrastructure of the infection of Sorghum bicolor by Colletotrichum sublineolum. Phytopathology 91, 149-158. 